\title{
PENGARUH BUDAYA ORGANISASI DAN LINGKUNGAN KERJA TERHADAP MOTIVASI KERJA SERTA DAMPAKNYA TERHADAP KEPUASAN KERJA KARYAWAN
}

\author{
Diah Pranitasari \\ Sekolah Tinggi Ilmu Ekonomi Indonesia Jakarta \\ Email : nitadpranitasari@gmail.com \\ Cici Bela Saputri \\ Sekolah Tinggi Ilmu Ekonomi Indonesia Jakarta \\ Email : cicibelasaputri@gmail.com
}

\begin{abstract}
ABSTRAK
Penelitian ini bertujuan untuk mengetahui (1) Pengaruh budaya organisasi terhadap motivasi kerja karyawan PT Posmi Steel Indonesia, (2) Pengaruh lingkungan kerja terhadap motivasi kerja karyawan PT Posmi Steel Indonesia, (3) Pengaruh budaya organisasi terhadap kepuasan kerja karyawan PT Posmi Steel Indonesia, (4) Pengaruh lingkungan kerja terhadap kepuasan kerja karyawan PT Posmi Steel Indonesia, (5) Pengaruh motivasi kerja terhadap kepuasan kerja karyawan PT Posmi Steel Indonesia, (6) Pengaruh budaya organisasi dan lingkungan kerja terhadap motivasi kerja karyawan PT Posmi Steel Indonesia, dan (7) Pengaruh budaya organisasi dan lingkungan kerja terhadap motivasi kerja dan kepuasan kerja karyawan PT Posmi Steel Indonesia. Sampel yang digunakan dalam penelitian ini adalah sebanyak 215 orang responden yang berasal dari karyawan tetap PT. Posmi Steel Indonesia. Uji statistik yang digunakan yaitu validitas, reliabilitas dan analisis jalur. Hasil perhitungan menunjukkan bahwa : (1) Budaya organisasi berpengaruh signifikan terhadap motivasi kerja karyawan PT Posmi Steel Indonesia, (2) Lingkungan kerja berpengaruh signifikan terhadap motivasi kerja karyawan PT Posmi Steel Indonesia, (3) Budaya organisasi berpengaruh signifikan terhadap kepuasan kerja karyawan PT Posmi Steel Indonesia, (4) Lingkungan kerja berpengaruh signifikan terhadap kepuasan kerja karyawan PT Posmi Steel Indonesia, (5) Motivasi kerja berpengaruh signifikan terhadap kepuasan kerja karyawan PT Posmi Steel Indonesia, (6) Budaya organisasi dan lingkungan kerja berpengaruh signifikan terhadap motivasi kerja karyawan PT Posmi Steel Indonesia, dan (7) Budaya organisasi dan lingkungan kerja berpengaruh signifikan terhadap motivasi kerja dan kepuasan kerja karyawan PT Posmi Steel Indonesia.
\end{abstract}

Kata Kunci : Budaya Organisasi, Lingkungan Kerja, Motivasi Kerja, Kepuasan Kerja Karyawan 


\section{PENDAHULUAN}

Sumber daya manusia mempunyai peran yang penting di dalam suatu perusahaan. Segala aspek yang berkaitan dengan sumber daya manusia pada akhirnya turut mempengaruhi output perusahaan yang bersangkutan. Mengingat peran yang sangat penting, sudah selayaknya suatu perusahaan melakukan pemeliharaan sumber daya manusia dengan memperhatikan kepuasan kerja para karyawan.

Persoalan kepuasan kerja akan dapat terlaksana dan terpenuhi apabila beberapa variabel yang mempengaruhi mendukung sekali. Variabel yang dimaksud adalah budaya, lingkungan dan motivasi kerja karyawan. Dapat dikatakan pula bahwa secara tidak langsung ketiga variabel tersebut mempengaruhi kinerja seorang karyawan dan berujung terhadap tercapainya target dari suatu perusahaan. Sehubungan dengan hal tersebut, agar karyawan selalu konsisten dengan kepuasannya maka setidak-tidaknya perusahaan selalu memperhatikan lingkungan di mana karyawan melaksanakan tugasnya misalnya rekan kerja, pimpinan, suasana kerja dan hal-hal lain yang dapat mempengaruhi kemampuan seseorang dalam menjalankan tugasnya.

Budaya organisasi yang berjalan dengan baik dapat meningkatkan kepuasan kerja seorang karyawan. Kepuasan kerja adalah kombinasi dari psikologis, keadaan fisiologis dan lingkungan, yang menyebabkan seseorang jujur, puas dengan/pekerjaannya (Neog dan Barua, 2014). Karyawan yang memiliki kepuasan kerja yang lebih tinggi biasanya lebih cenderung untuk tidak meninggalkan pekerjaan, lebih produktif, lebih menampilkan komitmen organisasi dan lebih mungkin puas dengan kehidupan mereka (Neog dan Barua, 2014).

Pranitasari (2019) menyatakan lingkungan kerja mempunyai pengaruh yang tinggi terhadap perilaku seseorang. Sebagai gambaran yang menunjukkan bahwa lingkungan kerja yang nyaman akan membawa dampak yang baik terhadap individu, demikian pula bila kondisi lingkungan buruk maka akan buruk pula dampaknya terhadap individu.

Motivasi kerja juga merupakan hal yang sangat penting untuk diperhatikan oleh pihak perusahaan bila menginginkan setiap karyawan dapat memberikan andil positif terhadap pencapaian tujuan perusahaan, karena dengan motivasi seorang karyawan akan memiliki semangat yang tinggi dalam melaksanakan tugas dan tanggung jawabnya. Pentingnya motivasi karena motivasi adalah hal yang menyebabkan, menyalurkan, dan mendukung perilaku manusia supaya mau bekerja giat dan antusias mencapai hasil yang optimal. 
Kepuasan kerja sebenarnya merupakan keadaan yang sifatnya subyektif yang merupakan hasil kesimpulan yang didasarkan pada suatu perbandingan mengenai apa yang diterima karyawan dari pekerjaannya dibandingkan dengan yang diharapkan, diinginkan, dan dipikirkannya sebagai hal yang pantas atau berhak atasnya. Sementara setiap karyawan secara subyektif menentukan bagaimana pekerjaan itu memuaskan.

Berikut ini adalah jumlah karyawan PT. Posmi Steel Indonesia selama tahun 2018 yang dirangkum pada Tabel 1:

Tabel 1. Jumlah Karyawan PT. Posmi Steel Indonesia Tahun 2018

\begin{tabular}{lcccccccccccc}
\hline Divisi & Jan & Feb & Mar & Apr & Mei & Jun & Jul & Ags & Sep & Okt & Nop & Des \\
\hline Management & 53 & 53 & 53 & 54 & 51 & 51 & 51 & 51 & 50 & 48 & 48 & 48 \\
Coil Centre Division & 136 & 135 & 134 & 135 & 136 & 134 & 132 & 130 & 129 & 128 & 129 & 126 \\
Stamping Division & 288 & 282 & 273 & 259 & 256 & 246 & 246 & 243 & 243 & 236 & 235 & 227 \\
Support Division & 44 & 44 & 43 & 43 & 43 & 43 & 42 & 42 & 42 & 41 & 41 & 41 \\
Grand Total & $\mathbf{5 2 1}$ & $\mathbf{5 1 4}$ & $\mathbf{5 0 3}$ & $\mathbf{4 9 1}$ & $\mathbf{4 8 6}$ & $\mathbf{4 7 4}$ & $\mathbf{4 7 1}$ & $\mathbf{4 6 6}$ & $\mathbf{4 6 4}$ & $\mathbf{4 5 3}$ & $\mathbf{4 5 3}$ & $\mathbf{4 4 2}$ \\
\hline Sumber: PT. Posmi Steel (2019) & & & & & & & & & &
\end{tabular}

Tabel 1 menggambarkan bahwa jumlah karyawan dari bulan Januari - Desember 2018 cenderung menurun. Penurunan yang paling dominan yaitu pada Divisi Coil Centre Division dan Divisi Stamping Division. Penurunan jumlah karyawan tidak dapat diketahui penyebabnya. Dengan latar belakang ini maka maka dirasa perlu dilakukan analisis Pengaruh Budaya Organisasi dan Lingkungan Kerja Terhadap Motivasi Kerja serta Dampaknya Terhadap Kepuasan Kerja Karyawan pada PT. Posmi Steel Indonesia.

\section{TELAAH PUSTAKA}

\section{Budaya Organisasi}

Riani (2014:7) budaya organisasi adalah nilai-nilai, keyakinan dan prinsip-prinsip dasar yang merupakan landasan bagi sistem dan praktek-praktek manajemen serta perilaku yang meningkatkan dan memperkuatkan prinsip-prinsip tersebut. Rivai dan Mulyadi (2014:374) bahwa budaya organisasi adalah suatu kerangka kerja yang menjadi pedoman tingkah laku sehari-hari dan membuat keputusan untuk karyawan dan mengarahkan tindakan mereka untuk mencapai tujuan organisasi.

Robbins dan Coulter (2014:80) budaya organisasi sebagai nilai-nilai, prinsip-prinsip, tradisi, dan cara cara bekerja yang dianut bersama oleh para anggota organisasi dan memengaruhi cara mereka bertindak. Schein (2015:27), budaya organisasi sebagai pola asumsi bersama yang dipelajari oleh suatu kelompok dalam memecahkan masalah melalui adaptasi eksternal dan integrasi internal, yang telah bekerja cukup baik untuk 
dipertimbangkan kebenarannya. Kreitner dan Kinicki (2014:62) budaya organisasi adalah nilai dan keyakinan bersama yang mendasari identitas perusahaan.

Berdasarkan uraian tersebut, bahwa budaya organisasi memiliki nilai-nilai, kebijakankebijakan dan peraturan yang diterapkan di dalam sebuah organisasi dijalankan dan ditaati oleh semua anggota organisasi dalam mencapai tujuan bersama. Tartika, Utami dan Muzkam (2017:12) menjelaskan indikator budaya organisasi terdiri dari inovasi dan pengambilan resiko, memperhatikan detail, orientasi pada hasil, orientasi individu, orientasi pada tim, keagresifan, dan stabilitas.

\section{Lingkungan Kerja}

Lingkungan kerja dalam suatu perusahaan perlu diperhatikan, hal ini disebabkan karena lingkungan kerja mempunyai pengaruh langsung terhadap para karyawan. Lingkungan kerja yang kondusif dapat meningkatkan kinerja karyawan dan sebaliknya, lingkungan kerja yang tidak memadai akan dapat menurunkan kinerja karyawan. Kondisi lingkungan kerja dikatakan baik apabila manusia dapat melaksanakan kegiatan secara optimal, sehat, aman dan nyaman. Kesesuaian lingkungan kerja dapat dilihat akibatnya dalam jangka waktu yang lama. Lingkungan kerja yang kurang baik dapat menuntut tenaga kerja dan waktu yang lebih banyak dan tidak mendukung diperolehnya rancangan sistem kerja yang efisien.

Robbins (2015:93) menyebutkan bahwa lingkungan adalah lembaga-lembaga atau kekuatan-kekuatan diluar yang berpotensi mempengaruhi kinerja organisasi, lingkungan dirumuskan menjadi dua yaitu lingkungan umum dan lingkungan khusus. Lingkungan umum adalah segala sesuatu di luar organisasi yang memilki potensi untuk mempengaruhi organisasi. Lingkungan ini berupa kondisi sosial dan teknologi. Sedangkan lingkungan khusus adalah bagian lingkungan yang secara langsung berkaitan dengan pencapaian sasaransasaran sebuah organisasi.

Lingkungan kerja yang dikemukakan oleh Amstrong dan Taylor dalam Pranitasari (2019), yaitu lingkungan kerja terdiri dari sistem kerja, desain pekerjaan dan manajer serta rekan kerja.

Pranitasari (2019) menjelaskan lingkungan kerja merupakan situasi di sekitar tempat kerja baik secara fisik maupun non-fisik yang dapat mempengaruhi kinerja karyawan dengan indikator: fisik (kondisi kerja, infrastruktur kerja dan kondisi administrasi) dan non-fisik (hubungan fisik antara pekerja, tempat kerja hubungan masyarakat dan kondisi kerja).

\section{Motivasi Kerja}


Mathis dan Jackson dalam Bangun (2014:312) motivasi adalah hasrat di dalam seseorang yang menyebabkan orang tersebut melakukan suatu tindakan dalam mencapai suatu tujuan. Kreitner dan Kinicki (2014:213) bahwa motivasi adalah kumpulan proses psikologis yang menyebabkan pergerakan (arousal), mengarahan (direction), dan kegigihan (persistence) dari sikap sukarela yang mengarah pada tujuan.

McShane dan Von Glinow (2014:132) motivasi adalah kekuatan dalam diri orang yang memengaruhi arah (direction), intensitas (intensity), dan ketekunan (presistence) perilaku sukarela. Karyawan yang termotivasi berkeinginan menggunakan tingkat usaha tertentu (intensity), untuk sejumlah waktu tertentu (presistence), terhadap tujuan tertentu (direction). Colquitt, LePine, dan Wesson pada buku perilaku dalam organisasi oleh Wibowo (2015:110) motivasi merupakan sekumpulan kekuatan energetik yang dimulai baik dari dalam maupun diluar pekerja, dimulai dari usaha yang berkaitan dengan pekerjaan, dan mempertimbahkan arah, intensitas dan ketekunannya.

Robbins dan Coulter (2014:459) motivasi adalah proses dimana usaha seseorang diberi energi, diarahkan dan berkelanjutan menuju tercapainya suatu tujuan. Hasibuan (2014:219) motivasi adalah pemberian daya penggerak yang menciptakan kegairahan kerja seseorang, agar mereka mau bekerja sama, bekerja efektif dan terintegrasi dengan segala daya upayanya untuk mencapai kepuasan.

Berdasarkan pada beberapa pendapat di atas dapat disimpulkan bahwa motivasi merupakan dorongan untuk bertindak terhadap serangkaian proses perilaku manusia dengan mempertimbangkan arah, intensitas, dan ketekunan pada pencapai tujuan. Rimpulaeng dan Sepang (2014) menyatakan bahwa indikator motivasi kerja adalah aktualisasi diri, penghargaan, kebutuhan social, kebutuhan rasa aman, dan kebutuhan fisik

\section{Kepuasan Kerja}

Suwarno dan Priansa (2014:263), kepuasan kerja adalah cara individu merasakan pekerjannya yang dihasilkan dari sikap individu tersebut terhadap berbagai aspek yang terkandung dalam pekerjaan. Pemahaman serupa juga dikemukakan oleh Wibowo (2014:501) yaitu kepuasan kerja adalah derajat positif atau negatifnya perasaan seseorang mengenai berbagai segi tugas-tugas pekerjaan, tempat kerja dan hubungan dengan sesama pekerja.

Hasibuan (2015:202), kepuasan kerja adalah sikap emosional yang menyenangkan dan mencintai pekerjannya. Sikap ini dicerminkan oleh moral kerja, kedisiplinan, dan prestasi kerja 
Berdasarkan beberapa pendapat di atas maka bahwa kepuasan kerja yang dirasakan setiap orang sangat berbeda ada banyak aspek yang mempengaruhinya. Beberapa aspek tersebut sangat penting guna menunjang tercapainya kepuasan kerja. Adanya pemenuhan kebutuhan yang dimiliki seseorang berdampak pada pencapaian nilai kerja seseorang atas pekerjaan yang telah dilaksanakannya.

Novita, Sunuharjo dan Ruhana (2016) menjelaskan indikator kepuasan kerja adalah prestasi, pengakuan, pekerjaan itu sendiri, pertumbuhan, dan kemajuan.

\section{METODE PENELITIAN}

Penelitian ini menggunakan pendekatan kuantitatif yaitu pendekatan yang didasarkan pada angka atau data kualitatif yang di angkakan (Sugiyono,2016:7). Sedangkan metode yang digunakan dalam penelitian ini adalah metode asosiatif yaitu penelitian yang bersifat menanyakan hubungan/pengaruh antara dua variabel atau lebih hubungan kausal adalah hubungan yang bersifat sebab-akibat (Sugiyono, 2016:36).

Populasi dalam penelitian ini adalah karyawan tetap di PT. Posmi Steel Indonesia yang tercatat aktif bulan Agustus 2018 sebanyak 466 karyawan. Teknik pengambilan sampel dalam penelitian ini proporsional random sampling. Untuk menetukan jumlah sampel yang mewakili populasi dalam penelitian digunakan rumus Slovin dan diperoleh jumlah sampel sebanyak 215 karyawan.

Analisis statistik data untuk penelitian ini menggunakan analisis jalur dikarenakan memiliki variabel bebas (2 variabel) yaitu variabel budaya organisasi $\left(\mathrm{X}_{1}\right)$ dan lingkungan kerja $\left(\mathrm{X}_{2}\right)$, variabel intervening yaitu motivasi kerja yang disimbolkan dengan $\left(\mathrm{Y}_{1}\right)$ dan variabel dependen yaitu kepuasan kerja yang disimbolkan dengan $\left(\mathrm{Y}_{2}\right)$. Persamaan analisis jalur dalam penelitian ini, dapat dilihat pada Gambar di bawah ini :

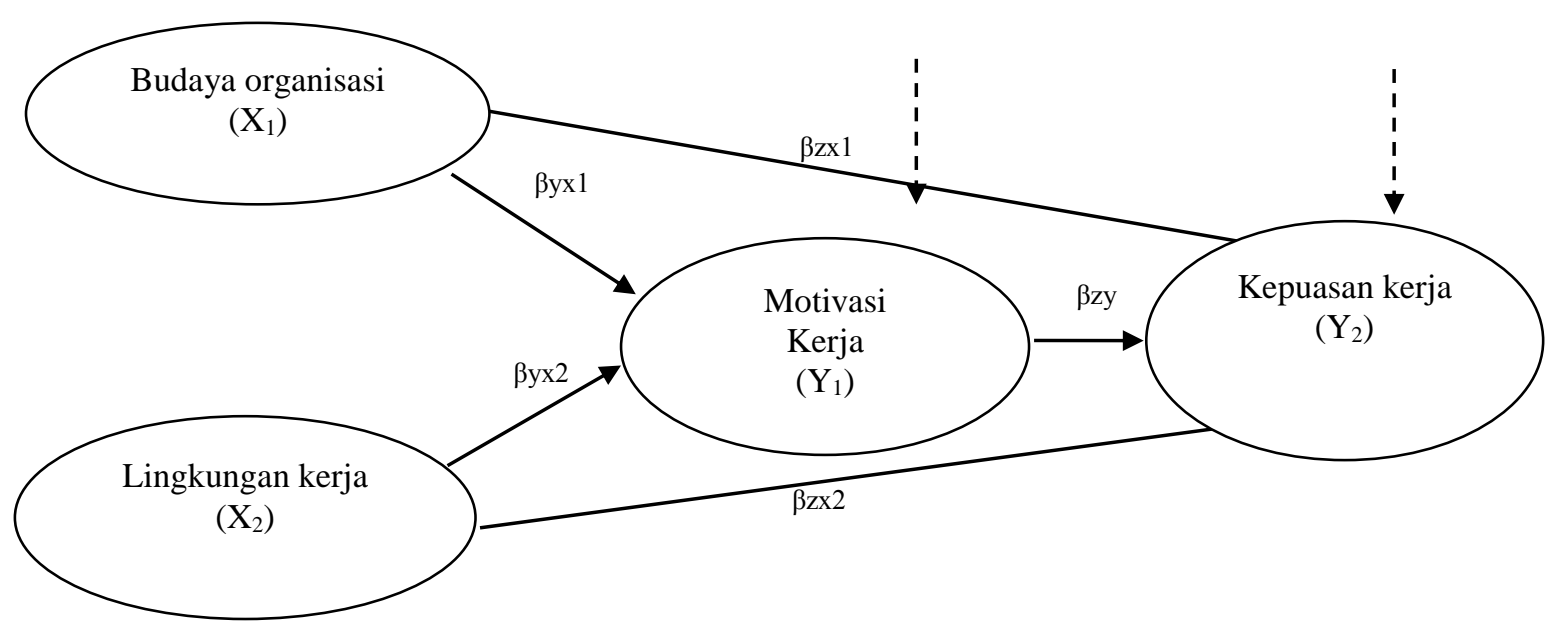


Gambar 1. Bagan Penelitian

\section{HASIL PENELITIAN}

Analisis jalur penelitian ini yaitu menggunakan uji yang terbagi menjadi dua jalur (Jalur 1 dan Jalur 2), yaitu sebagai berikut :

\section{Analisis Jalur 1}

Pengujian Analisis Jalur 1 ini terdiri dari variabel budaya organisasi dan lingkungan

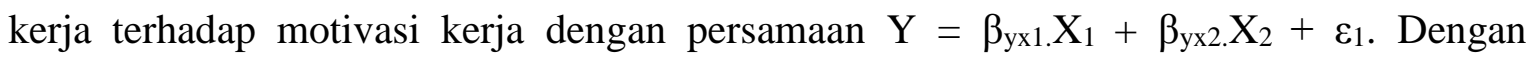
demikian dapat dirangkum dalam tabel 4.15. seperti dibawah ini :

Tabel 2. Rangkuman Hasil Analisis Jalur 1

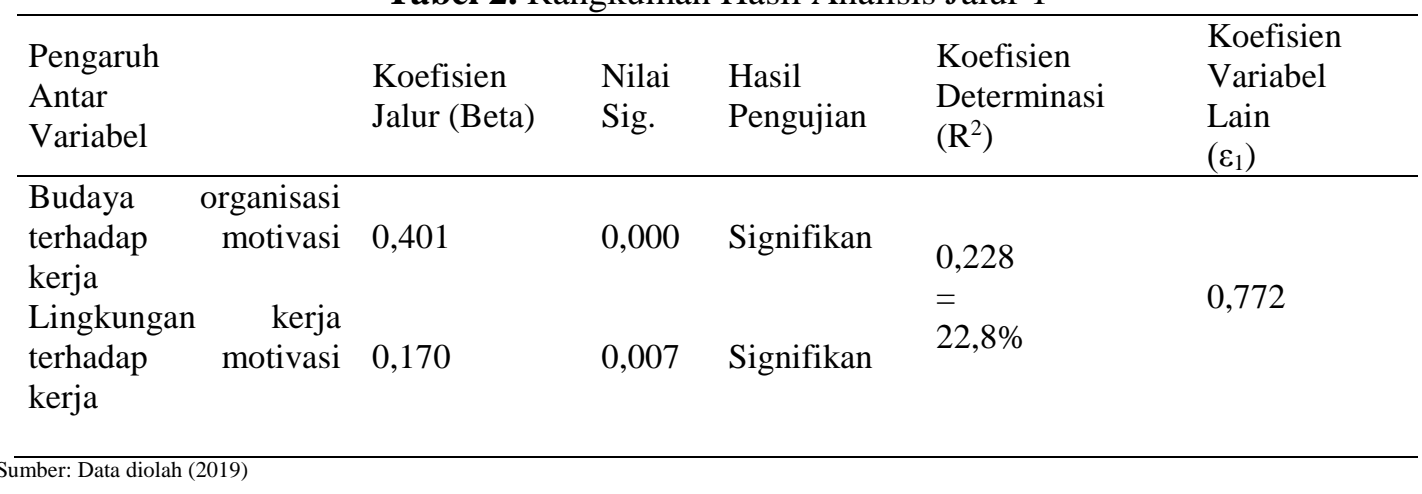

a). Koefisien (Berdasarkan tabel 4.15, diperoleh nilai Koefisien Analisis Jalur 1 sebagai berikut: $\mathrm{Y}=0,401 \mathrm{X}_{1}+0,170 \mathrm{X}_{2}+0,772$. Artinya besarnya pengaruh budaya organisasi terhadap motivasi kerja sebesar 40,1\%, besarnya pengaruh lingungan kerja terhadap motivasi kerja sebesar 17,0\%, sedangkan dipengaruhi oleh variabel diluar penelitian ini sebesar $77,2 \%$ ) b). Koefisien determinasi (Berdasarkan tabel 4.15, diperoleh nilai $\mathrm{R}^{2}$ sebesar 0,228. Hal ini menunjukkan bahwa secara simultan besarnya pengaruh variabel budaya organisasi dan lingungan kerja terhadap motivasi kerja pada PT. Posmi Steel Indonesia adalah 22,8\%, sedangkan sisanya dipengaruhi oleh variabel lain sebesar 77,2\%) c). Pengujian hipotesis (Berdasarkan hasil perhitungan SPSS yang tertuang dalam Tabel 4.15, diperoleh nilai sig untuk variabel budaya organisasi sebesar 0,000 . Hal ini menunjukkan bahwa secara parsial 
variabel budaya organisasi memiliki pengaruh yang signifikan terhadap motivasi kerja pada PT. Posmi Steel Indonesia yang ditunjukkan oleh nilai sig sebesar $0,000<0,05$ )

Selanjutnya perolehan nilai sig untuk variabel budaya organisasi dan lingkungan kerja sebesar 0,000 (Lampiran 7 output SPSS). Hal tersebut ditunjukkan dari perolehan nilai sig sebesar $0,000<0,05$, artinya secara simultan variabel budaya organisasi dan lingkungan kerja memiliki pengaruh yang signifikan terhadap motivasi kerja pada PT. Posmi Steel Indonesia yang ditunjukkan oleh nilai sig sebesar $0,000<0,05$.

a). Koefisien residu $\left(\varepsilon_{1}\right)$. Berdasarkan Tabel 4.15 , menunjukkan bahwa perolehan Jalur 1 untuk $\mathrm{R}^{2}$ sebesar $0,228=22,8 \%$ dan besarnya pengaruh faktor lain $\left(\varepsilon_{1}\right)$ yang mempengaruhi motivasi kerja diluar penelitian ini adalah sebesar $100 \%-22,8 \%=77,2 \%$.

Adapun gambar Analisis Jalur 1 adalah sebagai berikut :

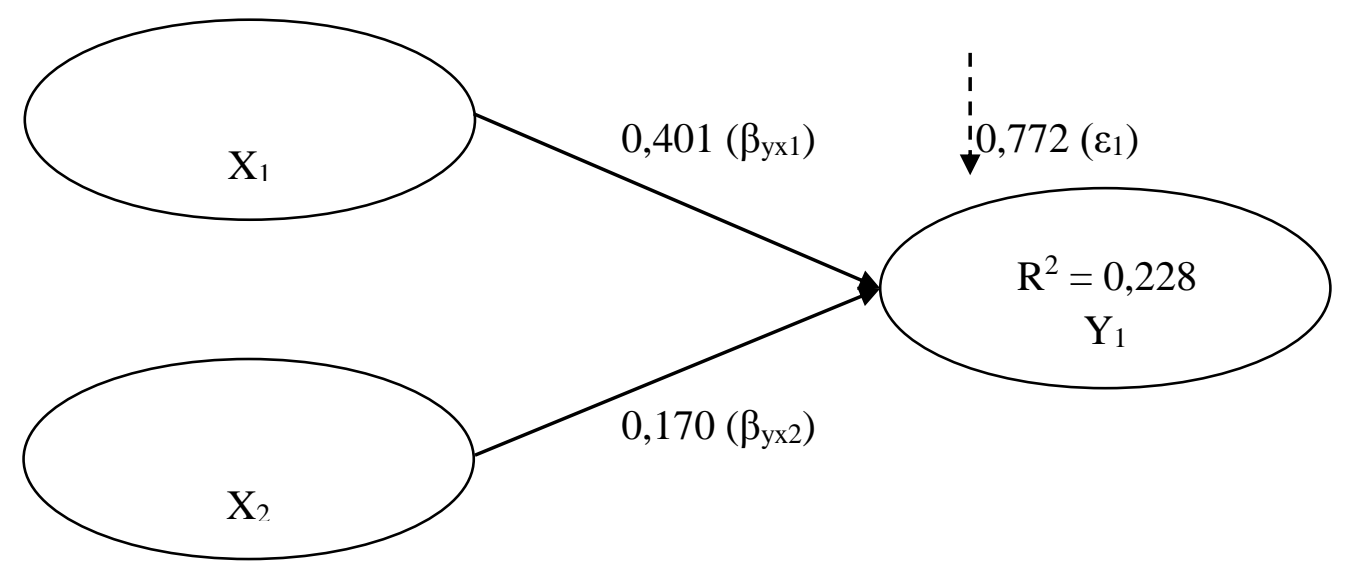

Gambar 2. Analisis Jalur 1

Adapun perolehan Analisis Jalur 1 sebagai berikut :

$\mathrm{Y}=0,401_{\mathrm{BO}}+0,170_{\mathrm{LK}}+0,772$ dan $\mathrm{R}^{2} 0,228$

2. Analisis Jalur 2

Pengujian Analisis Jalur 2 ini terdiri dari variabel budaya organisasi dan lingkungan kerja terhadap kepuasan kerja melalui motivasi kerja, yaitu $Y_{2}=\beta_{\mathrm{zx} 1} X_{1}+\beta_{\mathrm{zx} 2 .} X_{2}+\beta_{z y} . Y_{1}$ $+\varepsilon_{2}$. Dengan demikian dirangkum dalam Tabel 4.16. seperti dibawah ini :

Tabel 3. Rangkuman Hasil Analisis Jalur 2 


\section{Coefficients $^{\mathrm{a}}$}

\begin{tabular}{|c|c|c|c|c|c|c|}
\hline \multirow{2}{*}{\multicolumn{2}{|c|}{ Model }} & \multicolumn{2}{|c|}{$\begin{array}{l}\text { Unstandardized } \\
\text { Coefficients }\end{array}$} & \multirow{2}{*}{$\begin{array}{c}\text { Standardized } \\
\text { Coefficients } \\
\text { Beta } \\
\end{array}$} & \multirow[b]{2}{*}{$t$} & \multirow[b]{2}{*}{ Sig. } \\
\hline & & $\mathrm{B}$ & Std. Error & & & \\
\hline$\overline{1}$ & (Constant) & 8,674 & 4,632 & & 1,872 &, 063 \\
\hline & Budaya organisasi (X1) & ,155 & ,073 & , 156 & 2,121 & ,035 \\
\hline & Lingkungan kerja (X2) & , 175 &, 083 & 144 & 2,104 & ,037 \\
\hline & Motivasi kerja $(Y)$ & ,258 & , 117 & , 162 & 2,205 &, 029 \\
\hline
\end{tabular}

a. Dependent Variable: Kepuasan kerja (Z)

Sumber: Data diolah (2019)

a). Koefisien. Berdasarkan output SPSS yang tertuang pada Tabel 4.16, diperoleh nilai koefisien Jalur 2 sebagai berikut: $\mathrm{Y}_{2}=0,156 \mathrm{X}_{1}+0,144 \mathrm{X}_{2}+0,162 \mathrm{Y}_{1}+0,881$. Artinya besarnya pengaruh budaya organisasi terhadap kepuasan kerja sebesar 15,6\%, besarnya pengaruh lingkungan kerja terhadap kepuasan kerja sebesar 14,4\%, besarnya pengaruh motivasi kerja terhadap kepuasan kerja sebesar 16,2\% sedangkan dipengaruhi oleh variabel diluar penelitian ini sebesar $88,1 \%$. b). Koefisien determinasi. Berdasarkan output SPSS pada Tabel 4.16, diperoleh nilai $\mathrm{R}^{2}$ sebesar 0,119 . Hal ini menunjukkan bahwa secara simultan besarnya pengaruh variabel budaya organisasi dan lingkungan kerja terhadap kepuasan kerja melalui motivasi kerja pada PT. Posmi Steel Indonesia adalah 11,9\%, sedangkan sisanya dipengaruhi oleh variabel lain sebesar $88,1 \%$. c). Pengujian hipotesis. Berdasarkan Tabel 4.16, diperoleh nilai sig untuk variabel budaya organisasi sebesar 0,035 . Hal ini menunjukkan bahwa secara parsial variabel budaya organisasi memiliki pengaruh yang signifikan terhadap kepuasan kerja pada PT. Posmi Steel Indonesia yang ditunjukkan oleh nilai sig sebesar 0,035 $<0,05$. Adapun perolehan nilai sig untuk variabel lingkungan kerja sebesar 0,037 . Hal ini menunjukkan bahwa secara parsial variabel lingkungan kerja memiliki pengaruh yang signifikan terhadap kepuasan kerja pada PT. Posmi Steel Indonesia yang ditunjukkan oleh nilai sig sebesar $0,037<0,05$. Selanjutnya perolehan nilai sig untuk variabel motivasi kerja sebesar 0,029. Hal ini menunjukkan bahwa secara parsial variabel motivasi kerja memiliki pengaruh yang signifikan terhadap kepuasan kerja pada PT. Posmi Steel Indonesia yang ditunjukkan oleh nilai sig sebesar $0,029<0,05$.

Selanjutnya perolehan nilai sig untuk variabel budaya organisasi, lingkungan kerja dan motivasi kerja sebesar 0,000 (Lampiran 8 output SPSS), hal tersebut ditunjukkan dari perolehan nilai sig sebesar $0,000<0,05$, artinya secara simultan variabel budaya organisasi, lingkungan kerja memiliki pengaruh yang signifikan terhadap motivasi kerja dan kepuasan kerja pada PT. Posmi Steel Indonesia yang ditunjukkan oleh nilai sig sebesar 0,000 $<0,05$. 
a). Koefisien residu $\left(\varepsilon_{2}\right)$. Berdasarkan Tabel 4.16, menunjukkan bahwa perolehan Jalur 2 untuk $\mathrm{R}^{2}$ sebesar $0,119=11,9 \%$ dan besarnya pengaruh faktor lain yang mempengaruhi kepuasan kerja diluar penelitian ini adalah sebesar $100 \%-11,9 \%=88,1 \%$.

Adapun Gambar Analisis Jalur 2 adalah sebagai berikut :

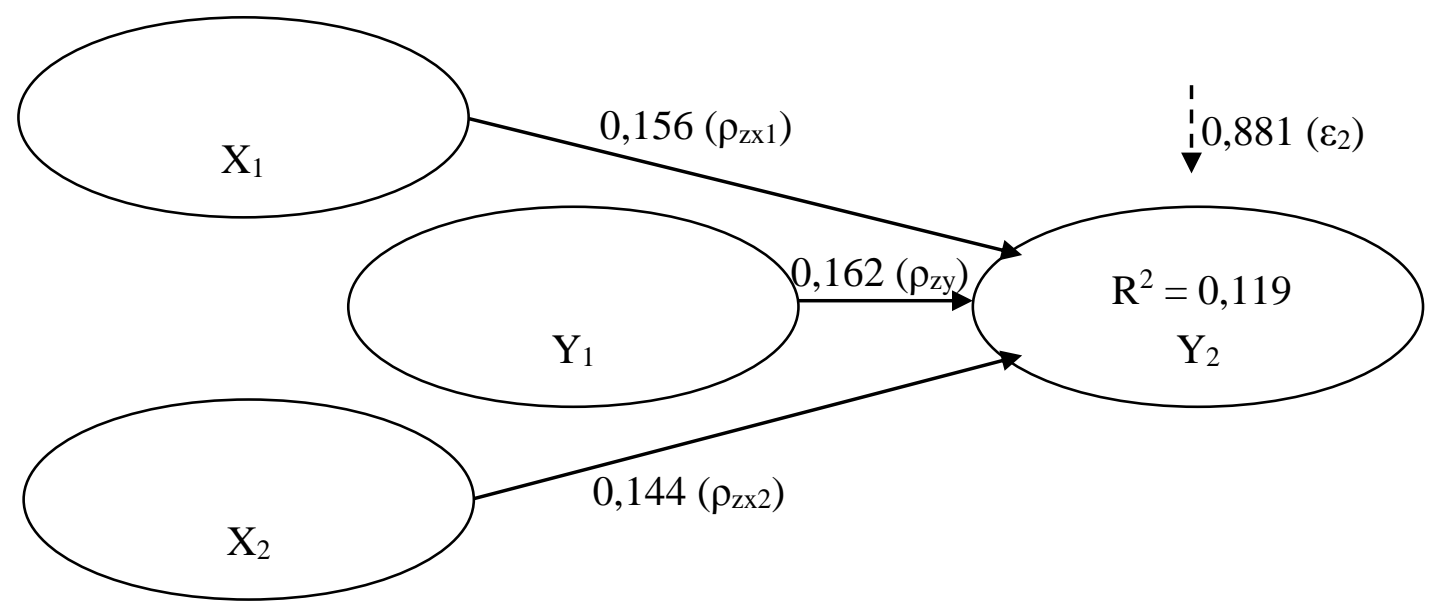

Gambar 3. Analisis Jalur 2

Perolehan Analisis Jalur 2 sebagai berikut :

$\mathrm{Y}_{2}=0,156_{\mathrm{BO}}+0,144_{\mathrm{LK}}+0,162_{\mathrm{MK}}+0,881$ dan $\mathrm{R}^{2} 0,119$

\section{Gabungan Analisis Jalur 1 dan Jalur 2}

Gambar di bawah ini adalah gabungan Analisis Jalur 1 dan Jalur 2 yaitu sebagai berikut :

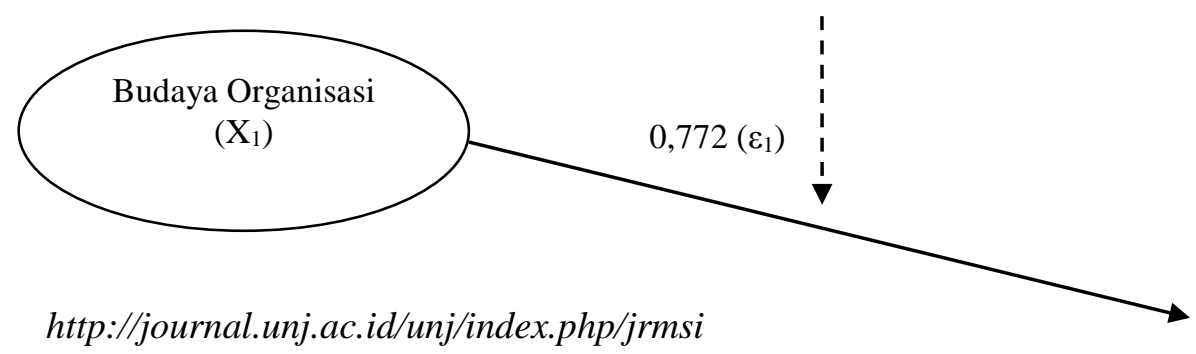

$0,881\left(\varepsilon_{2}\right)$ 


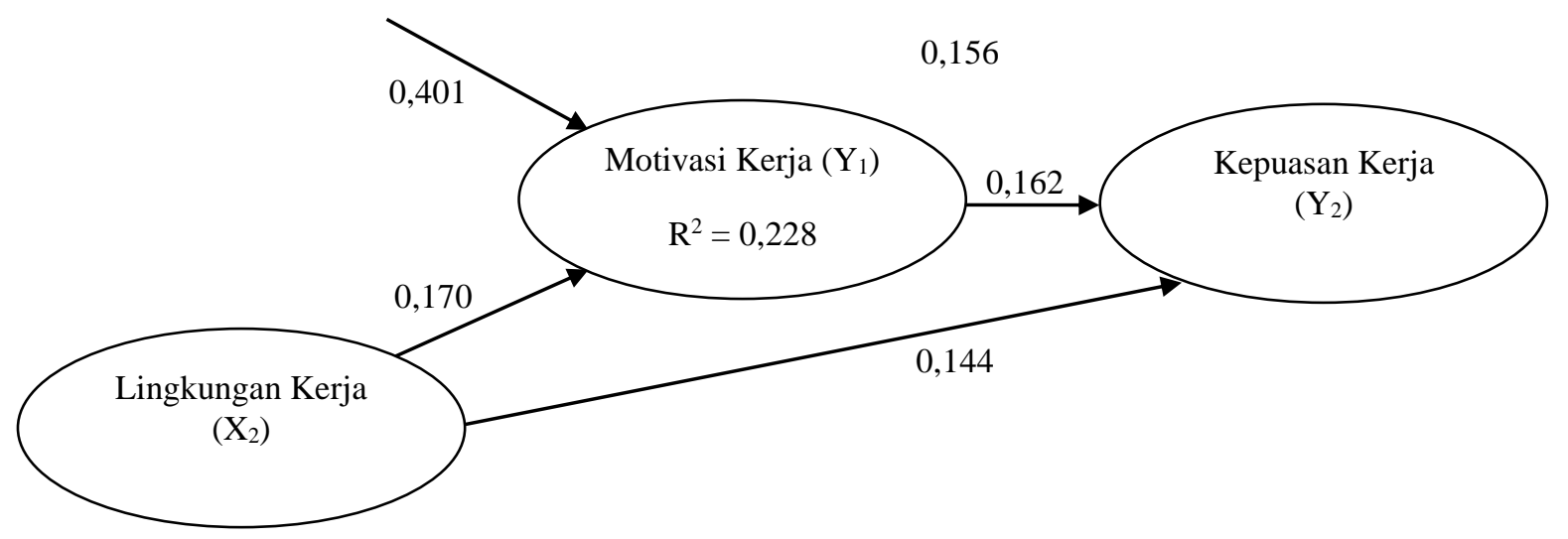

Gambar 4. Gabungan Analisis Jalur 1 dan Jalur 2

\section{PEMBAHASAN}

1). Pengaruh budaya organisasi terhadap motivasi kerja. Secara parsial variabel budaya organisasi memiliki pengaruh yang signifikan terhadap budaya organisasi pada PT. Posmi Steel Indonesia. Hasil penelitian ini sesuai dengan penelitian yang dilakukan oleh Giantari dan Riana (2017) bahwa budaya organisasi berpengaruh signifikan terhadap motivasi kerja. Dengan demikian, dapat disimpulkan bahwa jika budaya organisasi dalam suatu perusahaan berjalan dengan baik dan terarah, maka sebagian besar para karyawan akan termotivasi untuk dapat bekerja dengan maksimal, guna mewujudkan hasil kerja yang sesuai dengan keinginan dan harapan perusahaan. 2). Pengaruh lingkungan kerja terhadap motivasi kerja. Secara parsial variabel lingkungan kerja memiliki pengaruh yang signifikan terhadap motivasi kerja pada PT. Posmi Steel Indonesia. Hasil penelitian ini sesuai dengan penelitian yang dilakukan oleh Prakoso, Astuti dan Ruhana (2014) bahwa lingkungan kerja berpengaruh terhadap motivasi kerja karyawan. Dengan demikian, dapat disimpulkan bahwa jika lingkungan kerja dalam suatu perusahaan memberikan kenyamanan dan keamanan dalam menjalankan aktivitas kerja, maka sebagian besar para karyawan akan termotivasi untuk dapat bekerja dengan menunjukkan keahlian pada bidangnya masing-masing, dengan hal itu maka hasil kinerja para karyawan memberikan keuntungan bagi perusahaan secara menyeluruh. 3). Pengaruh budaya organisasi terhadap kepuasan kerja. Secara parsial variabel budaya organisasi memiliki pengaruh yang signifikan terhadap kepuasan kerja pada PT. Posmi Steel Indonesia. Hasil penelitian ini sesuai dengan penelitian yang dilakukan oleh Tumbelaka, Alhabsji, Nimran (2016) bahwa budaya organisasi berpengaruh signifikan terhadap kepuasan 
kerja karyawan. Dengan demikian, dapat disimpulkan bahwa jika budaya organisasi dalam suatu perusahaan berjalan sesuai dengan yang diharapkan, maka akan terwujud kepuasan kerja yang dirasakan oleh sebagian besar para karyawan, jika setiap karyawan sudah merasa puas maupun senang untuk bekerja, maka dalam menjalankan tugasnya masing-masing akan menciptakan kinerja yang profesional yang dapat diandalkan oleh perusahaan baik secara individu maupun secara tim. 4). Pengaruh lingkungan kerja terhadap kepuasan kerja. Secara parsial variabel lingkungan kerja memiliki pengaruh yang signifikan terhadap kepuasan kerja pada PT. Posmi Steel Indonesia. Hasil penelitian sejalan dengan penelitian terdahulu yang dilakukan oleh Hanafi dan Yohana (2017) bahwa lingkungan kerja berpengaruh signifikan terhadap kepuasan kerja. Dengan demikian, dapat disimpulkan bahwa jika lingkungan kerja antara hubungan atasan dengan karyawan maupun hubungan antar karyawan itu sendiri dalam terjalin dengan baik maka setiap karyawan akan merasakan ketenangan dan kesenangan setiap kali melakukan aktivitas kerja sehingga setiap karyawan akan mampu bekerja dengan maksimal dan optimal sesuai dengan tugasnya masing-masing. 5). Pengaruh motivasi kerja terhadap kepuasan kerja. Secara parsial variabel motivasi kerja memiliki pengaruh yang signifikan terhadap kepuasan kerja pada PT. Posmi Steel Indonesia. Hasil penelitian sesuai dengan penelitian terdahulu yang dilakukan oleh Hardiyana dan Nurhadian (2016) bahwa motivasi kerja berpengaruh signifikan terhadap kepuasan kerja karyawan. Dengan demikian, dapat disimpulkan bahwa jika setiap karyawan atau karyawan sudah memiliki motivasi dari dirinya sendiri maupun motivasi itu datangnya dari perusahaan yang akan memberikan penghargaan dan sejenisnya, maka karyawan akan bekerja dengan rasa puas dan senang sehingga proses kinerja dan hasil kinerja yang diharapkan perusahaan dapat terwujud dalam jangka pendek maupun jangka panjang. 6). Pengaruh budaya organisasi dan lingkungan kerja terhadap motivasi kerja karyawan. Secara simultan variabel budaya organisasi, lingkungan kerja memiliki pengaruh yang signifikan terhadap motivasi kerja pada PT. Posmi Steel Indonesia. Dengan demikian bahwa jika dalam perusahaan memiliki budaya organisasi dan lingkungan kerja yang baik maka setiap karyawan atau karyawan memiliki motivasi kerja yang tinggi dalam menyelesaikan pekerjaanya sehingga karyawan berdampak akan bekerja dengan motivasi kerja yang tinggi. 7). Pengaruh budaya organisasi dan lingkungan kerja terhadap motivasi kerja serta dampaknya terhadap kepuasan kerja karyawan Secara simultan variabel budaya organisasi, lingkungan kerja memiliki pengaruh yang signifikan terhadap motivasi kerja dan kepuasan kerja pada PT. Posmi Steel Indonesia. Dengan demikian bahwa jika dalam perusahaan memiliki budaya organisasi dan lingkungan 
kerja yang baik maka setiap karyawan atau karyawan memiliki motivasi kerja yang tinggi dalam menyelesaikan pekerjaanya sehingga ketika karyawan bekerja dengan motivasi kerja yang tinggi biasanya dalam proses menjalankan kinerjanya akan merasa puas terlebih lagi jika perusahaan memberikan penghargaan atau hadiah bagi karyawan yang menunjukkan kinerja yang baik. 8). Besarnya pengaruh budaya organisasi terhadap kepuasan kerja melalui motivasi kerja karyawan. Pengaruh tidak langsung budaya organisasi terhadap kepuasan kerja melalui motivasi kerja yaitu $(0,401 \times 0,162=0,064)$. Dengan demikian besarnya pengaruh tidak langsung budaya organisasi terhadap kepuasan kerja melalui motivasi kerja 6,4\%. 8). Besarnya pengaruh lingkungan kerja terhadap kepuasan kerja melalui motivasi kerja karyawan. Pengaruh tidak langsung lingkungan kerja terhadap kepuasan kerja melalui motivasi kerja yaitu $(0,170 \times 0,162=0,027)$. Dengan demikian besarnya pengaruh tidak langsung lingkungan kerja terhadap kepuasan kerja melalui motivasi kerja 2,7\%.

\section{KESIMPULAN}

1). Budaya organisasi berpengaruh signifikan terhadap motivasi kerja karyawan PT Posmi Steel Indonesia. Artinya, jika budaya organisasi di suatu perusahaan dapat dijalankan dengan baik, maka motivasi karyawan dalam melakukan aktivitas kerja akan meningkat. 2). Lingkungan kerja berpengaruh signifikan terhadap motivasi kerja karyawan PT Posmi Steel Indonesia. Artinya, jika lingkungan kerja di suatu perusahaan dapat dijalankan dengan baik, maka motivasi karyawan dalam melakukan aktivitas kerja akan meningkat. 3). Budaya organisasi berpengaruh signifikan terhadap kepuasan kerja karyawan PT Posmi Steel Indonesia. Artinya, jika budaya organisasi di suatu perusahaan dapat dijalankan dengan baik, maka kepuasan kerja yang dirasakan sebagian besar karyawan akan meningkat. 4). Lingkungan kerja berpengaruh signifikan terhadap kepuasan kerja karyawan PT Posmi Steel Indonesia. Artinya, jika lingkungan kerja di suatu perusahaan dapat dijalankan dengan baik, maka kepuasan karyawan dalam melakukan aktivitas kerja akan meningkat. 5). Motivasi kerja berpengaruh signifikan terhadap kepuasan kerja karyawan PT Posmi Steel Indonesia. Artinya, jika karyawan memiliki motivasi kerja yang tinggi, maka kepuasan karyawan dalam melakukan aktivitas kerja akan meningkat. 6). Budaya organisasi dan lingkungan kerja berpengaruh signifikan terhadap motivasi kerja karyawan PT Posmi Steel Indonesia. Artinya, jika budaya organisasi dan lingkungan kerja dapat dijalankan bersama-sama dengan baik, maka motivasi kerja karyawan akan meningkat. 7). Budaya organisasi dan lingkungan kerja 
berpengaruh signifikan terhadap motivasi kerja dan kepuasan kerja karyawan PT Posmi Steel Indonesia. Artinya, jika budaya organisasi, lingkungan kerja dan motivasi kerja dapat dijalankan bersama-sama dengan baik, maka kepuasan kerja karyawan akan meningkat. 8). Pengaruh tidak langsung budaya organisasi terhadap kepuasan kerja melalui motivasi kerja yaitu sebesar 6,4\%. 9). Pengaruh tidak langsung lingkungan kerja terhadap kepuasan kerja melalui motivasi kerja yaitu sebesar $2,7 \%$

\section{Saran}

Berdasarkan hasil pembahasan dan kesimpulan yang diuraikan di atas, maka peneliti memberikan saran sebagai berikut :

1). Budaya organisasi. Skor terendah pada variabel budaya organisasi yaitu mengenai pernyataan "Saya lebih senang menyelesaikan pekerjaan dengan kerja sama tim". Peneliti menyarankan agar setiap karyawan berupaya untuk selalu meningkatkan pekerjaan baik secara individu maupun kerja sama tim, agar keinginan perusahaan dapat tercapai. 2). Lingkungan kerja. Skor terendah pada variabel lingkungan kerja yaitu mengenai pernyataan "Saya memiliki keterampilan yang unik sehingga menjadi nilai tambah bagi pimpinan perusahaan". Peneliti menyarankan agar setiap karyawan meningkatkan kemampuan dan keterampilan kerja yang dimiliki, agar harapan pimpinan dan perusahaan dapat terwujud. 3). Motivasi kerja. Skor terendah pada variabel motivasi kerja yaitu mengenai pernyataan "Saya bekerja untuk memenuhi kebutuhan sehari-hari khususnya makan dan minum". Peneliti menyarankan agar setiap karyawan meningkatkan motivasi, baik itu motivasi dari diri sendiri maupun motivasi eksternal agar dapat bekerja dengan optimal, sehingga perusahaan memberikan kompensasi maupun gaji untuk memenuhi kebutuhan karyawan dalam kehidupan sehari-hari. 4). Kepuasan kerja. Skor terendah pada variabel kepuasan kerja yaitu mengenai pernyataan "Sudah banyak pengalaman yang saya peroleh dalam pekerjaan saya". Peneliti menyarankan agar setiap karyawan meningkatkan kinerja berdasarkan pengalaman yang pernah dimiliki, sehingga mampu mendapatkan hasil kinerja yang sesuai dengan harapan perusahaan maupun harapan dari karyawan itu sendiri.

\section{DAFTAR PUSTAKA}

Bangun, Wilson. 2014. “Manajemen Sumber Daya Manusia”. Jakarta: Erlangga.

Giantari dan Riana (2017), E-Jurnal Manajemen Unud, Vol. 6, No. 12, 2017: 6471-6498 ISSN : 2302-8912, Fakultas Ekonomi dan Bisnis Universitas Udayana, Bali, 
Indonesia, "Pengaruh Budaya Organisasi terhadap Motivasi Kerja dan Kinerja Karyawan PT. Bali Indo Steel”.

Hanafi dan Yohana (2017), Jurnal Pendidikan Ekonomi dan Bisnis (JPEB) Vol.5 No.1 Maret E-ISSN:2302-2663, Universitas Negeri Jakarta, dengan judul "Pengaruh Motivasi, dan Lingkungan Kerja, Terhadap Kinerja Karyawan, Dengan Kepuasan Kerja Sebagai Variabel Mediasi Pada PT. Bintang Mulya Baja Steel”.

Hardiyana, Nurhadian (2016), Jurnal Ekonomi, Bisnis \& Entrepreneurship Vol. 10, No. 2, Oktober, 104-118 ISSN 2443-0633, STIE Pasundan, Bandung, "Pengaruh Kompensasi Dan Motivasi Kerja Terhadap Kepuasan Kerja Serta Implikasinya Pada Kinerja Karyawan PT. Perintis Karya Pasundan”.

Hasibuan, Malayu. 2014. Manajemen Sumber Daya Manusia. Jakarta: Bumi Aksara. http://administrasibisnis.studentjournal.ub.ac.id/index.php/jab/article/viewFile/596/79 5 ( 11 Juni 2018 )

Kenly Rimpulaeng, Jantje L. Sepang (2014), Jurnal Emba: Jurnal Riset Ekonomi, Manajemen, Bisnis Dan Akuntansi VOL 2, NO 3 (2014) Hal 116 -235ISSN: 23031174: Motivasi Kerja, Komitmen Karyawan, Dan Budaya Organisasi, Pengaruhnya Terhadap Kinerja Karyawan PT. Gudang Garam Manado.

Kreitner, Kinicki. 2014. Organizational Behavior. New York: McGraw-Hill

McShane, Steven L., dan Von Glinow, Mary Ann. 2014. Organizational Behavior: Emerging Knowledge and Practice for The Real World. New York : The McGraw-Hill Company.

Neog, Bidyut Bijoya., Barua, Dr. Mukulesh (2014), Factors Influencing Employee's Job Satisfaction: An Empirical Study among Employees of Automobile Service Workshop in Assam, The SIJ Transactions on Industrial, Financial \& Business Management (IFBM), Vol. 2, No. 7, September 2014.

Neog, Bidyut Bijoya., Barua, Dr. Mukulesh. 2014. Factors Influencing Employee's Job Satisfaction: An Empirical Study among Employees of Automobile Service Workshop in Assam, The SIJ Transactions on Industrial, Financial \& Business Management (IFBM), Vol. 2, No. 7, September 2014.

Novita, Bambang Swasto Sunuharjo, Ika Ruhana (2016), Jurnal Administrasi Bisnis (JAB) Vol. 34 No. 1 Mei 2016: Pengaruh Kepuasan Kerja Dan Komitmen Organisasional Terhadap Kinerja Karyawan (Studi Pada PT. Telekomunikasi Indonesia, Tbk Witel Jatim Selatan, Malang). administrasibisnis.studentjournal.ub.ac.id.

Prakoso, Rayka Dantyo., Endang Siti Astuti., dan Ika Ruhana. 2014. Pengaruh Lingkungan Kerja Terhadap Motivasi Kerja Dan Kinerja Karyawan (Studi Pada Karyawan PT. AXA Financial Indonesia Cabang Malang). Jurnal Administrasi Bisnis (JAB). Volume 14. Nomor 2, September 2014. 
Pranitasari, Diah. 2019. Keterikatan Kerja: Dosen Sebagai Kunci Keberhasilan Perguruan Tinggi. Jakarta: Deepublish.

Pranitasari, Diah. 2019. Key Success Factors of Lecturer"s Work Engagement at College of Economics. Journal of Engineering and Applied Sciences 14 (11): 3615-3619, 2019. http://medwelljournals.com/abstract/?doi=jeasci.2019.3615.3619. http://docsdrive.com/pdfs/medwelljournals/jeasci/2019/3615-3619.pdf

Pranitasari, Diah; Trianah, Lilik; Taufik, Muhammad. Pengaruh Budaya Organisasi Dan Lingkungan Kerja Terhadap Motivasi Kerja. Media Manajemen Jasa Vol. 6 No. 2 2018. http://journal.uta45jakarta.ac.id/index.php/MMJ/article/view/1403

Riani, Laksmi Asri. 2014. Manajemen SDM Masa Kini, Yogyakarta : Graha Ilmu

Rivai, Veitzhal dan Mulyadi, Deddy. 2014. Kepemimpinan dan Perilaku Organisasi. Jakarta: PT Raja Grafindo Persada

Robbins, S.P dan Judge T.A. 2015. Perilaku Organisasi. Jakarta: Salemba Empat

Robbins, Stephen P. dan Coulter, Mary. 2014. Manajemen. Jakarta: PT. Indeks

Schein, Edgar H. 2015. Organizational Culture and Leadership, Third Edition, Jossey -Bass Publishers, San Francisco

Steven Set Xaverius Tumbelaka, Taher Alhabsji, Umar Nimran (2016) Jurnal Bisnis dan Manajemen Vol. 3 No.1, Januari 2016: Pengaruh Budaya Organisasi Terhadap Kepuasan Kerja, Komitmen Organisasional Dan Intention To Leave (Studi Pada Karyawan Pt.Bitung Mina Utama).

Sugiyono. 2016. Metode Penelitian Pendidikan Pendekatan Kuantitatif, kualitatif, dan R\&D. Bandung: Alfabeta

Suwatno \& Priansa, D. 2015. Manajemen SDM dalam organisasi Publik dan Bisnis. Bandung: Alfabeta.

Wibowo. 2014. Manajemen Kinerja. Jakarta: raja Grafindo Persada 